\title{
Green synthesis and characterization of silver and iron nanoparticles using Nerium oleander extracts and their antibacterial and anticancer activities
}

\author{
(1) Shalima Shawuti 1, (1) Chasan Bairam 2, Ahmet Beyatlı ${ }^{3}$, (๑) İshak Afşin Kariper ${ }^{4}$, (1) Isık Neslişah \\ Korkut ${ }^{1}$, @ Zerrin Aktaş ${ }^{5}$, @ Mustafa Oral Öncül ${ }^{6}$, @ Serap Erdem Kuruca ${ }^{1}$ \\ ${ }^{1}$ Department of Physiology, Faculty of Medicine, Istanbul University, Turgut Özal Millet str., 34093 Istanbul, Turkey \\ 2 Renewable Energy and Oxide Hybrid Systems Laboratory, Department of Physic, Faculty of Science, Istanbul University, \\ Şehzadebaşı str., 34134 Istanbul, Turkey \\ ${ }^{3}$ Department of Medicinal and Aromatic Plants, Hamidiye Vocational School of Health Services, University of Health Sciences, \\ Tıbbiye str. 38, 34668 Istanbul, Turkey \\ ${ }^{4}$ Faculty of Education, Erciyes University, Yenidoğan Mahallesi, Turhan Baytop Sokak str. 1, 38280 Kayseri, Turkey \\ ${ }^{5}$ Department of Microbiology, Faculty of Medicine, Istanbul University, Turgut Özal Millet str., 34093 Istanbul, Turkey \\ ${ }^{6}$ Department of Infectious Diseases, Faculty of Medicine, Istanbul University, Turgut Özal Millet str., 34093 Istanbul, Turkey
}

Received: 19.08.2021 | Accepted: 21.11.2021 | Published online: 28.11.2021

\begin{abstract}
Medicinal plants can be used as reducing agents in the preparation of metal nanoparticles by green synthesis because of the chemotherapeutic and anti-infectious properties of natural compounds. Therefore, this paper reports the green synthesis of silver and iron nanoparticles from leaf and flower extracts of Nerium oleander and their capacity as anticancer and antimicrobial agents. Nanoparticle manufacturing and structural characterization of silver and iron nanoparticles are reported. The formation of nanoparticles is characterized by scanning electron microscopy with energy dispersive X-ray spectroscopy, UV-Vis and Fourier transform infrared (FTIR) spectroscopy. Nanoparticles formation was also investigated the surface charge, particle size, and distribution using zeta sizer analysis by DLS. Green synthesis of silver and iron nanoparticles using $N$. oleander showed different levels of selective cytotoxicity against K562 (human chronic myeloid leukemia cells) in low concentrations and were not cytotoxic to the HUVEC (human umbilical vein endothelial cells) in the same concentrations. Silver nanoparticles showed antibacterial activity against multidrug pathogens, while iron nanoparticles failed to show such activity. Results of the present research demonstrate the potential use of green synthesized nanoparticles in various biomedicine and pharmaceuticals fields in the future.
\end{abstract}

Keywords: Nerium oleander, green synthesis, Ag-nanoparticles, Fe-nanoparticles, cellular cytotoxicity, antibacterial effect

\footnotetext{
Authors' contributions: Shalima Shawuti is principle investigator. Chasan Bairam is master student who carried out XRD and UV-Vis analysis. Ahmet Beyatı is researcher collect and prepare leafs extract; also did phytochemical screening test, İshak Afşin Kariper is researcher who perform SEM and DLS analysis. Isık Neslişah Korkut is master student who investigate the cytotoxic test, Zerrin Aktaş and Mustafa Oral Öncül are collaborators who perform antibacterial tests and write evaluation on those part. Finally, Serap Erdem Kuruca is co-principle investigator and supervisor.
}

Funding: This work was also supported by the Scientific Research Projects Coordination Unit of Istanbul University.

Competing Interests: We wish to confirm that there are no known conflicts of interest with this publication and there has been no significant financial support for this work that could have influenced its outcome. We confirm that the manuscript has been read and approved by all named authors and that there are no other persons who satisfied the criteria for authorship but are not listed. We further confirm that the order of authors listed in the manuscript has been approved by all of us. 


\section{Introduction}

Nanoparticles (NPs) are synthesized generally by expensive chemical synthesis methods that require the use of toxic chemicals. Thus, using biomolecules (i.e., bacteria, fungi, or plants) for NPs synthesis became a common method in past years that is safe, low-cost, and ecofriendly. Different plant extracts can be act as safe natural capping, reducing, and stabilizing agents without being a source of thermal or chemical hazards (Fedlheim \& Foss, 2001; Arya, 2010). Nanoparticles formation can be a glimmer of hope for the production of drugs that can be used against infectious diseases and cancer.

Nerium oleander L. (Apocynaceae), grown in wetlands of the Mediterranean region, can be seen wild as well cultivated as an ornamental plant in parks and gardens. It is an evergreen shrub with pink and white flowers (Baytop, 1999). The plant grows up to $2-6 \mathrm{~m}$ tall. The leaves are in pairs or whorls of three, thick and leathery, dark-green, narrowly lanceolate, 5-21 cm long, and with an entire margin. Flowers develop in clusters at the end of branches, the diameter of each flower range about $2.5-5 \mathrm{~cm}$ with a deeply 5-lobed fringed corolla around the central corolla tube. The fruit is a long narrow capsule $5-23 \mathrm{~cm}$ long, which splits open at maturity to release numerous downy seeds (Baytop, 1999; Kiran \& Prasad, 2014).

The leaves and flowers of $N$. oleander used in folkloric medicine among people in Turkey for rheumatism and urticaria (Bulut \& Tuzlaci, 2013; Sağıroğlu et al., 2013). The latex of plant used for eczema (Gürdal \& Kültür, 2013). Over the world, different parts of this plant are used traditionally for the treatment of various human ailments, including dermatitis, eczema, herpes, skin cancer, asthma, epilepsy, malaria, and tumors (Santhi, 2011). Nerium oleander is considered one of the most poisonous plants in the world which leads annually to the death of many people and animals (Rubini et al., 2019). This toxicity is due to toxins like oleandrin, oleandrigenin, and nerine, which belong to cardiac glycosides (Al-Badrani et al., 2008; Zibbu \& Batra, 2010). In addition, the plant contains terpenoids and steroids (Santhi, 2011).

Despite the toxicity of plant, different scientific studies conducted on various parts of
N. oleander showed its antibacterial (Chauhan et al., 2017), hepatoprotective and antioxidant (Singhal \& Gupta, 2012), antiproliferative (Wong et al., 2011), antidiabetic (Sikarwar et al., 2009), anti-inflammatory (Erdemoglu et al., 2003), and anticancer (Pathak et al., 2000; Turan et al., 2006) activities. This study was aimed to synthesize $\mathrm{Ag}$ and Fe nanoparticles using leaves and flowers of $N$. oleander and then evaluate its antibacterial and anticancer activity against human chronic myeloid leukemia cell line.

\section{Material and methods}

\section{Chemicals and reagents}

An anhydrous $\mathrm{FeCl}_{3}$ with $98 \%$ purity (Merck, Germany), $\mathrm{AgNO}_{3}$ with $99.5 \%$ purity (SigmaAldrich, USA) were used as metal sources. Dulbecco's modified Eagle medium (DMEM) and fetal bovine serum (FBS) (Gibco, UK) and MTT (3-[4,5-dimethylthiazol-2-yl]-2,4diphenyltetrazolium bromide) were applied. All reagents used were of analytical grades.

\section{Plant material}

Nerium oleander leaves and flowers were collected from Servetiye Village, Sakarya Province, Turkey in June 2020. Plant was identified at the Herbarium of Faculty of Pharmacy, Istanbul University (voucher number - ISTE-117270).

\section{Preparation of extracts}

Collected dried leaves and flowers of $N$. oleander were washed thoroughly (three times) in distilled water and homogenized using a mortar and pestle. The shade dried leaves and flowers of $\mathrm{N}$. oleander were powdered and then $10 \mathrm{~g}$ of both leaves and flowers were suspended in $100 \mathrm{ml}$ of distilled water. Mixtures stirred for $20 \mathrm{~min}$ at $60^{\circ} \mathrm{C}$, then allowed to cool at room temperature, and then filtered using a Whatman no. 42 filter paper and centrifuged at $\times 2000 \mathrm{rpm}$ for 20 min (Byrne et al., 2016). The extracts prepared were then transferred to a sterile container. The extracts were stored at $4{ }^{\circ} \mathrm{C}$ and freshly used.

\section{Preliminary phytochemicals screening}

Nerium oleander extracts were subjected to qualitative screening for the presence 
Table 1. $\mathrm{pH}$ values of the NO-AgNPs and NO-FeNPs. The $\mathrm{pH}$ values were measured on leaf extract, after mixing with a metal salt, and after 24 hours of mixing.

\begin{tabular}{llll}
\hline Formation & Extract $\mathrm{pH}$ & Extract $+\mathrm{Metal} \mathrm{NO}_{3}(\mathrm{Oh})$ & Extract $+\mathrm{metal}_{\mathrm{NO}}(24 \mathrm{~h})$ \\
\hline NOL-AgNPs & 6.78 & 6.56 & 4.21 \\
NOF-AgNPs & 5.42 & 6.12 & 3.74 \\
NOL-FeNPs & 6.78 & 2.32 & 2.17 \\
NOF-FeNPs & 5.42 & 2.33 & 2.25 \\
\hline
\end{tabular}

of various phytochemicals using standard procedures (Tyler, 1993; Harborne, 1998).

\section{Preparation of Nerium oleander silver nanoparticles (NO-AgNPs)}

$2.5 \mathrm{~mL}$ from the leaf $(\mathrm{L})$ and flower (F) extract solutions were taken and mixed with $1 \mathrm{mM}$ $\mathrm{AgNO}_{3}$ in $47.5 \mathrm{~mL}$ deionized water and a solution of $50 \mathrm{~mL}$ in amount was obtained. The $\mathrm{pH}$ values of crude leaf and flower extracts, $\mathrm{pH}$ values of samples just after mixing with $\mathrm{AgNO}_{3}$ metal source and after $24 \mathrm{~h}$ were measured (Table 1). The $\mathrm{pH}$ of the prepared $\mathrm{AgNO}_{3}$ solution was 5.28.

\section{Preparation of Nerium oleander iron nanoparticles (NO-FeNPs)}

Same sample preparation steps were followed for iron nanoparticles. Briefly, $5 \mathrm{~mL}$ from the leaf and flower extract solutions was taken and mixed with $0.2 \mathrm{M} \mathrm{FeCl}_{3}$ in $45 \mathrm{~mL}$ deionized water and a solution of $50 \mathrm{~mL}$ in amount was obtained. The $\mathrm{pH}$ values of crude leaf and flower extracts, $\mathrm{pH}$ values of samples just after mixing with $\mathrm{FeCl}_{3}$ and after $24 \mathrm{~h}$ were measured (Table 1). The pH of the prepared $\mathrm{FeCl}_{3}$ solution was 2.25.

\section{Characterization of Nerium oleander AgNPs and FeNPs}

The synthesized nanoparticles were characterized through a UV-Vis spectrophotometer Shimadzu 2600. The reduction of nanoparticles was monitored by UV-spectrophotometer range of absorbance from 250-480 $\mathrm{nm}$. The crystalline structures of the green-synthesized N. oleander (AgNP) and (FeNP) were examined by XRD Rigaku Flex 600 (600 models, with $\lambda=1.5406$ and with a step size of $0.02 \AA$ ) at speed of $3^{\circ}$ $\mathrm{min}^{-1}$. Particle size and zeta potential were measured by Malvern Nano ZS. Morphology and elemental metal mapping were recorded using a high-resolution scanning electron microscope (SEM, Carl Zeiss Ultra Plus Gemini Fesem) were used to investigate 2D surface morphologies. The composition analyses of the samples were performed by EDX (EDX spectrometer attached to SEM). Fourier transformed infrared (FTIR) analyses were carried out on a liquid sample with Bruker Alpha FTIR spectrometer in the range from $4000-500 \mathrm{~cm}^{-1}$. The device had a DTGS detector and ten scans were conducted for each spectrum with resolution four.

\section{Cytotoxic assay}

K562 (human chronic myeloid leukemia cells) and HUVEC (human umbilical vein endothelial cells) cell lines were obtained from American Type Culture Collection (ATCC). Cells were cultured in DMEM with $10 \%$ FBS and $1 \%$ penicillin/streptomycin in a $5 \% \mathrm{CO}_{2}$ humidified incubator, maintained at $37^{\circ} \mathrm{C}$. First, N. oleander nanoparticles were sterilized and diluted with DMEM to prepare four different dilutions which are 1, 1/2,1/5, and $1 / 10$. MTT assays were performed in 96-well plates. The plant extract and metal concentrations found in these nanoparticle dilutions are also shown in Table 2. K562 cells (about 105 cells per well) were seeded and incubated for $72 \mathrm{~h}$. Then, supernatants were removed, and $10 \mu \mathrm{L}$ (MTT - $5 \mathrm{mg} / \mathrm{mL}$ ) solution was added to each well. Following incubation at $37^{\circ} \mathrm{C}$ for $3.5 \mathrm{~h}$ and kept dark in a humidified atmosphere at $5 \% \mathrm{CO}_{2}$ in the air. Subsequently, the supernatant was discarded, and the precipitated formazan was dissolved in dimethyl sulfoxide $(100 \mu \mathrm{L}$ per well). The optical density of the solution was evaluated using a microplate spectrophotometer at a wavelength of $570 \mathrm{~nm}$ (Mosmann, 1983). GraphPad Prism was used to calculate cell viability and $\mathrm{IC}_{50}$ values. 
Table 2. The nanoparticle dilutions used in cytotoxicity tests.

\begin{tabular}{lllll}
\hline Dilutions & NOF-Ag & NOL-Ag & NOF-Fe & NOL-Fe \\
\hline 1 & $500 \mathrm{ug} / \mathrm{mL}$ & $500 \mathrm{ug} / \mathrm{mL}$ & $1000 \mathrm{ug} / \mathrm{mL}$ & $1000 \mathrm{ug} / \mathrm{mL}$ \\
& $20 \mathrm{uM} / \mathrm{mL}$ & $20 \mathrm{uM} / \mathrm{mL}$ & $1 \mathrm{mM} / \mathrm{mL}$ & $1 \mathrm{mM} / \mathrm{mL}$ \\
$1 / 2$ & $250 \mathrm{ug} / \mathrm{mL}$ & $250 \mathrm{ug} / \mathrm{mL}$ & $500 \mathrm{ug} / \mathrm{mL}$ & $500 \mathrm{ug} / \mathrm{mL}$ \\
& $10 \mathrm{uM} / \mathrm{mL}$ & $10 \mathrm{uM} / \mathrm{mL}$ & $0.5 \mathrm{mM} / \mathrm{mL}$ & $0.5 \mathrm{mM} / \mathrm{mL}$ \\
$1 / 5$ & $100 \mathrm{ug} / \mathrm{mL}$ & $100 \mathrm{ug} / \mathrm{mL}$ & $200 \mathrm{ug} / \mathrm{mL}$ & $200 \mathrm{ug} / \mathrm{mL}$ \\
& $4 \mathrm{uM} / \mathrm{mL}$ & $4 \mathrm{uM} / \mathrm{mL}$ & $0.02 \mathrm{mM} / \mathrm{mL}$ & $0.02 \mathrm{mM} / \mathrm{mL}$ \\
$1 / 10$ & $50 \mathrm{ug} / \mathrm{mL}$ & $50 \mathrm{ug} / \mathrm{mL}$ & $100 \mathrm{ug} / \mathrm{mL}$ & $100 \mathrm{ug} / \mathrm{mL}$ \\
& $2 \mathrm{uM} / \mathrm{mL}$ & $2 \mathrm{uM} / \mathrm{mL}$ & $0.01 \mathrm{mM} / \mathrm{mL}$ & $0.01 \mathrm{mM} / \mathrm{mL}$ \\
\hline
\end{tabular}

\section{Antibacterial activity}

The antibacterial potential was tested against 14 different human pathogenic bacteria including three Gram-negative bacteria (Escherichia coli ATCC 35218, clinical isolates of carbapenem-resistant Klebsiella pneumoniae (CRKpn) and carbapenemresistant E. coli (CREc)) and 11 Gram-positive bacteria (Staphylococcus aureus ATCC 29213 and ATCC 25923, inducible-clindamycinresistant S. aureus (ICRSa) BAA976-1, heteroresistant S. aureus (hVISA), clinical isolates of methicillin-resistant S. aureus (MRSA), methicillin-resistant coagulase-negative S. aureus (MR-CoNS:2), vancomycin-resistant Enterococcus faecium (VREf), E. faecalis ATCC 29212 and 51279, and vancomycin susceptible E. faecalis (VSEf)). The species were identified by using the Vitek 2 system (bioMerieux Vitek Inc.).

Antibacterial activity was detected by minimum inhibition concentrations (MICs), which were determined by serial microdilution method (MIC ranges - 2.5-0.0012 mg/L for NOL-AgNPs and NOF-AgNPs, and 5.0$0.0024 \mathrm{mM}$ for $\mathrm{AgNO}_{3}$ ) following CLSI (2018). Briefly, $100 \mu \mathrm{L}$ of each concentration were added to a well (96-well microplate) containing $100 \mu \mathrm{L}$ of Mueller Hinton Broth (MHB) and $10 \mu \mathrm{L}$ of inoculum (0.5 McFarland; $1.5 \times 108$ colony forming units $/ \mathrm{mL}$ ). Plates were then incubated at $37^{\circ} \mathrm{C}$ for $24 \mathrm{~h}$. Bacterial growth was determined by absorbance at $600 \mathrm{~nm}$.

\section{List of applied abbreviations}

ATCC - American Type Culture Collection

CREc - carbapenem-resistant Escherichia coli CRKpn - carbapenem-resistant Klebsiella pneumoniae
DLS - dynamic light scattering

DMEM - Dulbecco's modified Eagle medium

FBS - fetal bovine serum

FTIR - Fourier transform infrared

HUVEC - human umbilical vein endothelial cells

hVISA - heteroresistant Staphylococcus aureus $\mathrm{IC}_{50}$ - half maximal inhibitory concentration

ICRSa - inducible clindamycin-resistant S. aureus

K562 - human chronic myeloid leukemia cells

MIC - minimum inhibition concentrations

MR-CoNS:2 - methicillin-resistant coagulasenegative $S$. aureus

MRSA - methicillin-resistant S. aureus

NO - Nerium oleander

$\mathrm{NOF}-\mathrm{N}$. oleander flowers extract

NOL - N. oleander leaves extract

NPs - nanoparticles

SEM - scanning electron microscopy

UV-Vis - Uv-Vis spectroscopy

VREf - vancomycin-resistant Enterococcus faecalis

VSEf - vancomycin-susceptible E. faecalis XRD - X-ray spectroscopy

\section{Results and discussion}

\section{Preliminary phytochemicals screening}

Qualitative phytochemical analysis of $\mathrm{N}$. oleander extracts showed the presence of different active components in the aqueous extracts (Table 3). Previous works on $\mathrm{N}$. oleander revealed the presence of alkaloids, flavonoids, glycosides, tannins, terpenoids, and saponins in this plant 
Table 3. Preliminary phytochemical screening of leaves and flowers of Nerium oleander extract (plus and minus indicate the presence and absence of the chemicals, respectively).

\begin{tabular}{lll}
\hline Phytochemicals & Leaves & Flowers \\
\hline Alkaloids & + & + \\
Flavonoids & - & + \\
Saponins & + & + \\
Terpenoids & - & - \\
Steroids & - & - \\
Tannins & + & + \\
Glycosides & + & + \\
\hline
\end{tabular}

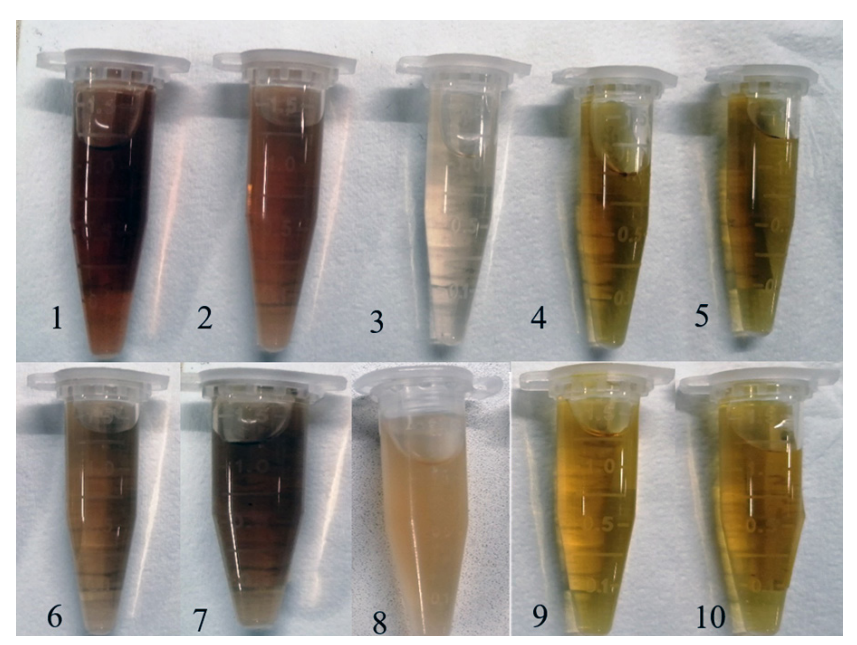

Figure 1. Synthesis of $\mathrm{Ag}$ and Fe nanoparticles exhibit color change. First row - solutions fabricated with leaf extracts (1 - NOL-Ag; 2 - NOL-Ag after $24 \mathrm{~h}$; 3 - crude NOL extract; 4 - NOL-Fe; 5 - NOL-Fe after $24 \mathrm{~h})$. Second row - solutions fabricated with flower extracts (6 - NOF-Ag; 7 NOF-Ag after 24 h; 8 - crude NOF extract; 9 - NOF-Fe; 10 - NOF-Fe after 24 h).

(Chaudhary et al., 2015; Saranya et al., 2017). The existence of these constituents can be the main reason behind the biological activity.

\section{Synthesis of Fe/Ag NPs by visual inspection}

After $24 \mathrm{~h}$ of reaction, the reaction solution color changed from light to dark color, which can be seen in Fig. 1. The reduction of $\mathrm{Fe}^{+}$ ions exhibits a dark color due to the excitation of surface plasmon vibration in a metal nanoparticle. Similarly, in the reduction of $\mathrm{Ag}^{+}$ions, the solution color change from light pink to light yellow. Visual photo images of the NOF-NPs are not reported due to similarity in colors with NOL-NPs.

\section{SEM and DLS measurement}

The scanning electron microscopy (SEM) technique was used to evaluate the morphology and size of the green synthesized NOL-AgNPs. Fig. 2 represents the surface images and DLS size distribution of green synthesized nanoparticles (NO-AgNPs). Specifically, the nanoparticles appear aggregated and spread uniform shapes. Iron nanoparticles seem also spherical with $70 \mathrm{~nm}$ average diameters. In another study, silver nanoparticles from N. oleander flowers were synthesized (Bharathi \& Shanthi, 2017). Silver particles of about $10 \mu \mathrm{m}$ by SEM analysis are very small compared to ours, but we do not know their effectiveness as authors did not repot their bioactivity. Besides, such small particles are not suitable for clinical use as they will be much easier to eliminate by the immune system (Bharathi \& Shanthi, 2017).

The zeta potential is an indicator of surface charge potential, which is an important parameter for understanding the stability of nanoparticles in aqueous suspensions. Table 4 summarizes DLS size distribution measurements carried out on green synthesized NPs. For the NOF-FeNPs, the average particle size was $1872 \mathrm{~nm}$ with a polydispersity index of 0.69 (zeta potential - +5.3 mV). On the other hand, particle sizes of NOF-AgNPs were found $76 \mathrm{~nm}$ size with relatively homogenous distribution (polydispersity index -0.266 , zeta potential - +8.1 mV). Secondly, For the NOL-FeNPs, the average particle size was $609 \mathrm{~nm}$ with a polydispersity index of 0.54 (zeta potential - $+7.4 \mathrm{mV}$ ). On the other hand, particle sizes of NOL-AgNPs were found $93 \mathrm{~nm}$ size with relatively homogenous distribution (polydispersity index - 0.364, zeta potential - +8.8 mV). No aggregation of the colloidal was observed for several months. Therefore, it may suggest that all synthesized NOF-NPs and NOL-NPs were highly stable when stored at the required temperature. It was also observed that produced NPs had positively charged on their surface with zeta potential values above $5 \mathrm{mV}$.

\section{UV spectroscopy}

The characterization of silver and iron nanoparticles by UV-spectrophotometer from the range of $350-900 \mathrm{~nm}$ was performed to monitor the reduction of metal ions and their 

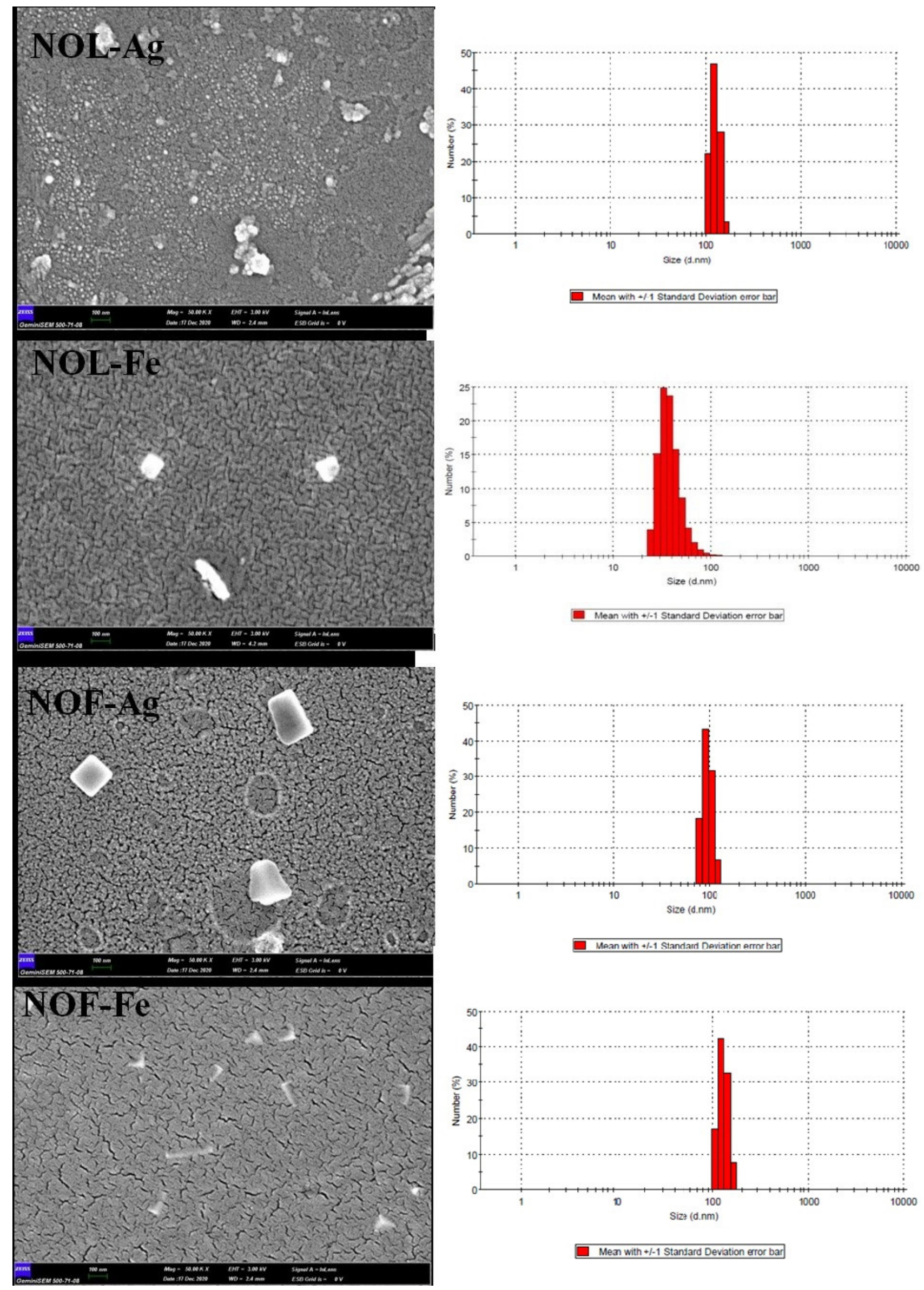

Mean with $+1-1$ Stanjard Deviation error bar

Figure 2. SEM image and DLS size distribution of Nerium oleander related NPS. The SEM images were obtained on dried powder samples. 
Table 4. The DLS, polydispersity index, and zeta potential of NO-NPs.

\begin{tabular}{llll}
\hline Formation & Average diameter $(\mathrm{nm})$ & Polydispersity index & Zeta potential $(\mathrm{mV} \pm \mathrm{SD})$ \\
\hline NOF-FeNPs & 130.0 & 0.690 & $+5.3 \pm 9.3$ \\
NOF-AgNPs & 76.1 & 0.266 & $+8.1 \pm 0.3$ \\
NOL-FeNPs & 39.1 & 0.251 & $+7.4 \pm 0.4$ \\
NOL-AgNPs & 92.9 & 0.364 & $+8.8 \pm 0.8$ \\
\hline
\end{tabular}

stability. The broad absorption peaks in the range from 326 to $432 \mathrm{~nm}$ were represented in Fig. 3. UV-Vis spectra were performed for NO-AgNPs and NO-FeNPs fabricated with leaf and flower extracts. To observe any shift, both crude NOL and NOF were also investigated. The absorption peaks of a plant extract with an organic mixture were not able to record since they are belonging to $\mathrm{C}-\mathrm{C}$ and $\mathrm{C}-\mathrm{H}$ electronic transitions (below $250 \mathrm{~nm}$ wavelength). The absorption peaks for NOF at 326 and $384 \mathrm{~nm}$ wavelengths belong to the $n-\pi^{*}$ and $\pi-\pi^{*}$ transitions (Wang et al., 2014). It is because this plant extract contains carbon-carbon double bonds, nitrogen-oxygen bonds, or cyclic aromatic structures. This absorption peak was only seen at $366 \mathrm{~nm}$ for NOL. While Ag nanoparticle synthesized with NOF gives an absorption peak at $432 \mathrm{~nm}$ as expected. The synthesized Fe NP continued to interact with functional groups in the plant extract, and while a specific $435 \mathrm{~nm}$ absorption peak was observed in the region belonging to a typical metal nanoparticle, an absorption peak appeared at $377 \mathrm{~nm}$ due to its interaction with functional groups. Another possible explanation for this phenomenon is that the Fe nanoparticle can be in $\mathrm{Fe}_{2} \mathrm{O}_{3}$ or $\mathrm{Fe}_{3} \mathrm{O}_{4}$ structure types (Wang et al., 2014). UV-Vis spectra with the NOL nanoparticles showed much clearer absorption peaks of metal nanoparticles compared to a case in NOF. The Ag NPs absorption peak was observed at $437 \mathrm{~nm}$ whereas the Fe NPs was detected at $408 \mathrm{~nm}$.

\section{XRD analysis}

The crystalline structures of the greensynthesized NOL-FeNPs, NOF-FeNPs NOFAgNPs, and NOF-AgNPs were furtherly examined by XRD analysis. The obtained patterns were demonstrated in Fig. 4 with labeled indices together with two theta values. The obtained diffraction peaks at $2 \theta$ values of $23.5^{\circ}, 26.6^{\circ}, 35.8^{\circ}, 39.1^{\circ}$, and $46.2^{\circ}$ were assigned to (012), (120), (110), (113) and (202) lattice planes, respectively. Those sets of lattice planes were identical to those reported for standard iron metal. For NOL-FeNPs, the iron nanoparticles are FCC and crystalline (cubic crystalline structure, $\mathrm{a}=4.07100 \AA$ Å; JCPDS files no. 84-0713 and 04-0783). NO-AgNPs are FCC
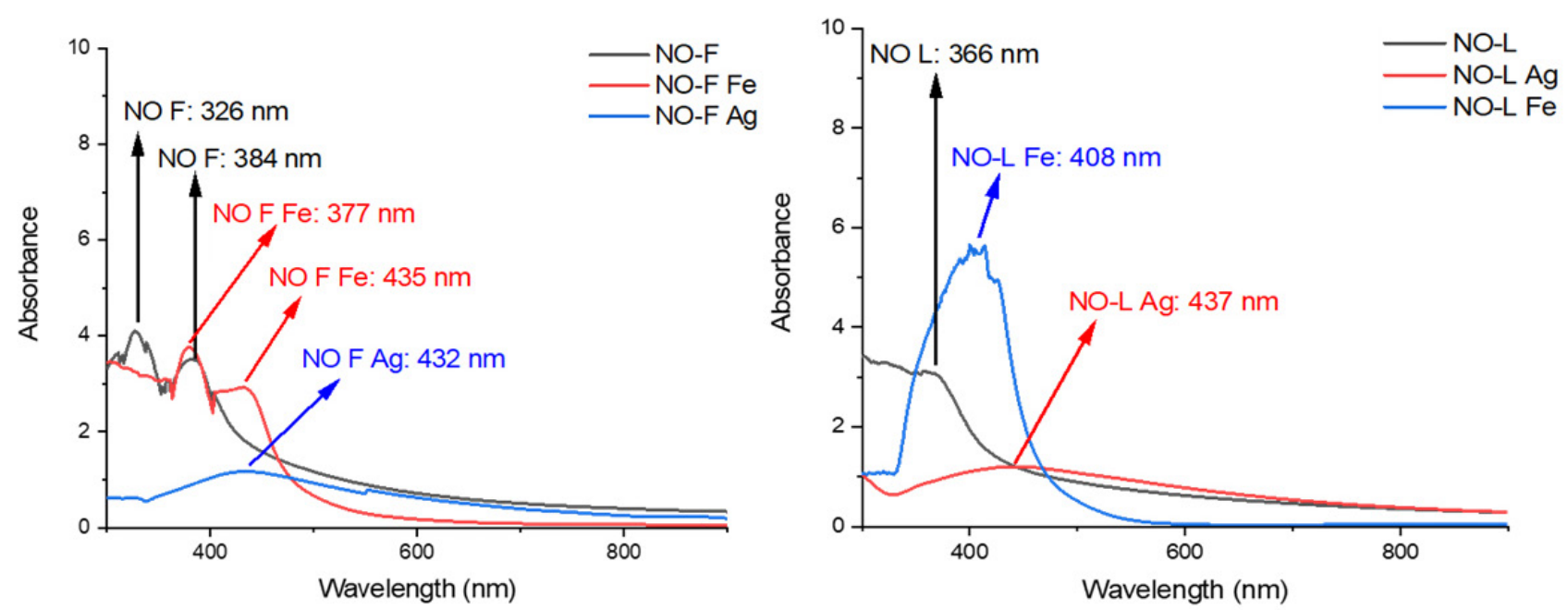

Figure 3. UV-Vis of NOL and NOF extracts and NO-FeNPs and NO-AgNPs. 

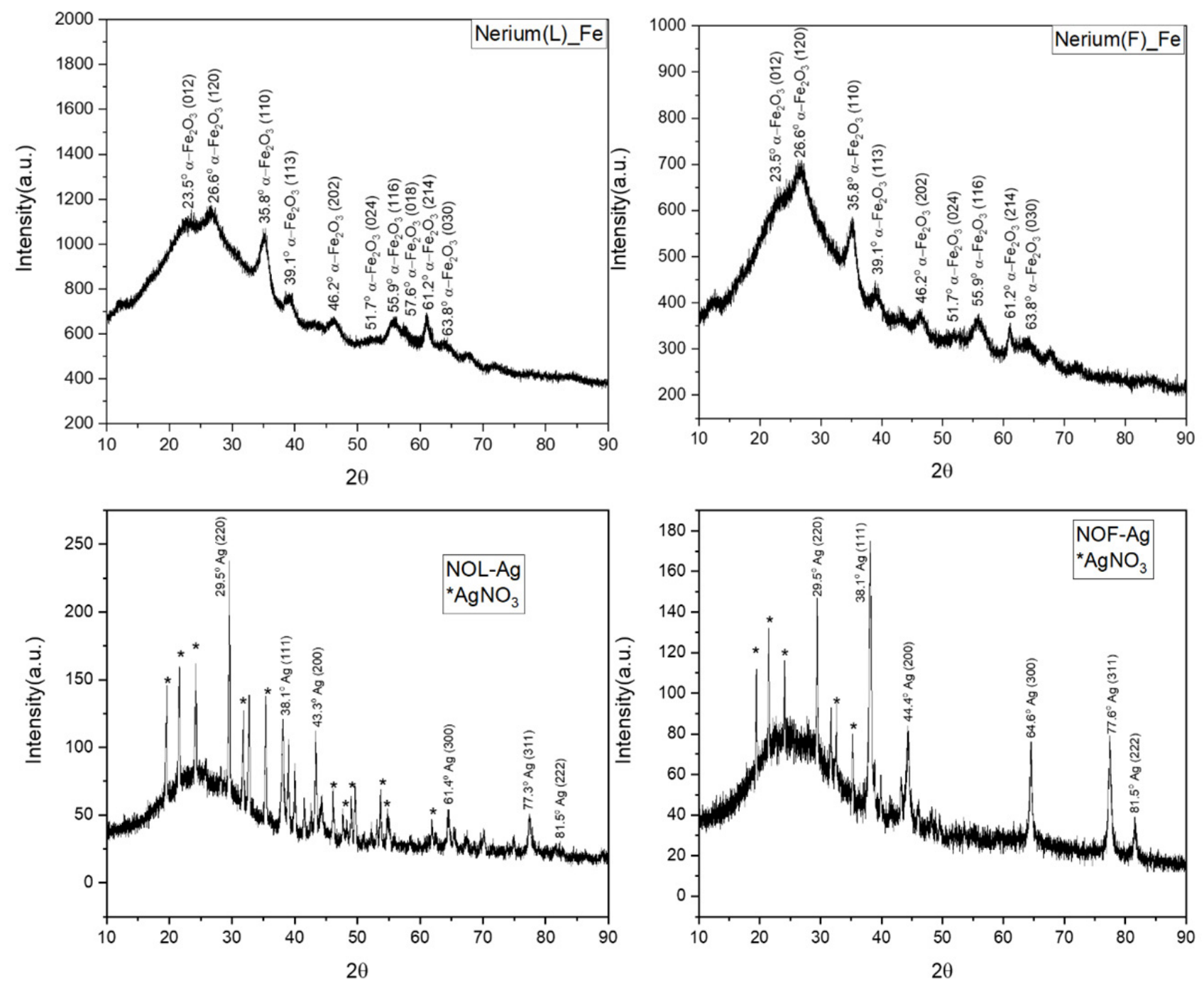

Figure 4. XRD graphs of NOL-Fe, NOF-Fe, NOL-Ag, and NOF-Ag.

and crystalline (cubic crystalline structure, $\mathrm{a}=4.07100 \AA$; JCPDS files no. 84-0713 and 040783). The obtained diffraction peaks at $2 \theta$ values of $26.50^{\circ}, 36.78^{\circ}$, and $38.40^{\circ}$ were assigned to (220), (111), and (111) lattice planes, respectively. Those sets of lattice planes were identical to those reported for standard silver metal (JCPDS files no. 84-0713 and 04-0783).

\section{FTIR analysis}

FTIR spectra of NOF and NOF-NPs are presented in Fig. 5. The absorption band at $3300 \mathrm{~cm}^{-1}$ was mainly attributed to $\mathrm{OH}$ vibration. The absorption peaks were assigned to the stretching vibration of $\mathrm{C}=\mathrm{C}$ $\left(1645 \mathrm{~cm}^{-1}\right)$. Compared to NOF extract's FTIR, the disappearance of the most functional group is due to the successful reduction of metal ions. Three main bands were demonstrated in the FTIR spectrum of both NOF-FeNPs and NOF-AgNPs The presence of
$\mathrm{OH}$ bonds and $\mathrm{C}=\mathrm{O}$ functional groups on the NOF-AgNPs and NOF-AgNPs were presented at $3244 \mathrm{~cm}^{-1}$ and $1633 \mathrm{~cm}^{-1}$, respectively. It was reported in the literature that FeNPs exhibit a characteristic stretching $\mathrm{Fe}-\mathrm{O}$ vibration peak at $576 \mathrm{~cm}^{-1}$ (Wang et al., 2014). For NOFAgNPs, stretching vibrations at $631 \mathrm{~cm}^{-1}$ can also be attributed to the reduction of $\mathrm{Ag}^{+}$to Ag. In similar green synthesis studies also reported observation of reduction of $\mathrm{Ag}^{+}$to $\mathrm{Ag}$ peak at around $538 \mathrm{~cm}^{-1}$ (Erdogan et al., 2019). The FTIR spectrums of NOL-Ag and NOL-Fe are similar to the FTIR spectrums of NOF-Ag and NOF-Fe. Therefore, there was no need to reinterpret the NOL-Ag and NOLFe spectrums.

\section{Cytotoxicity assay}

NOL-AgNPs are effective in the K562 cancer cell line $\left(\mathrm{IC}_{50}-2.3 \mathrm{uM}\right)$. However, NOF-AgNPs are variable $\left(\mathrm{IC}_{50}-10 \mathrm{uM}\right)$. Similarly, NOF- 


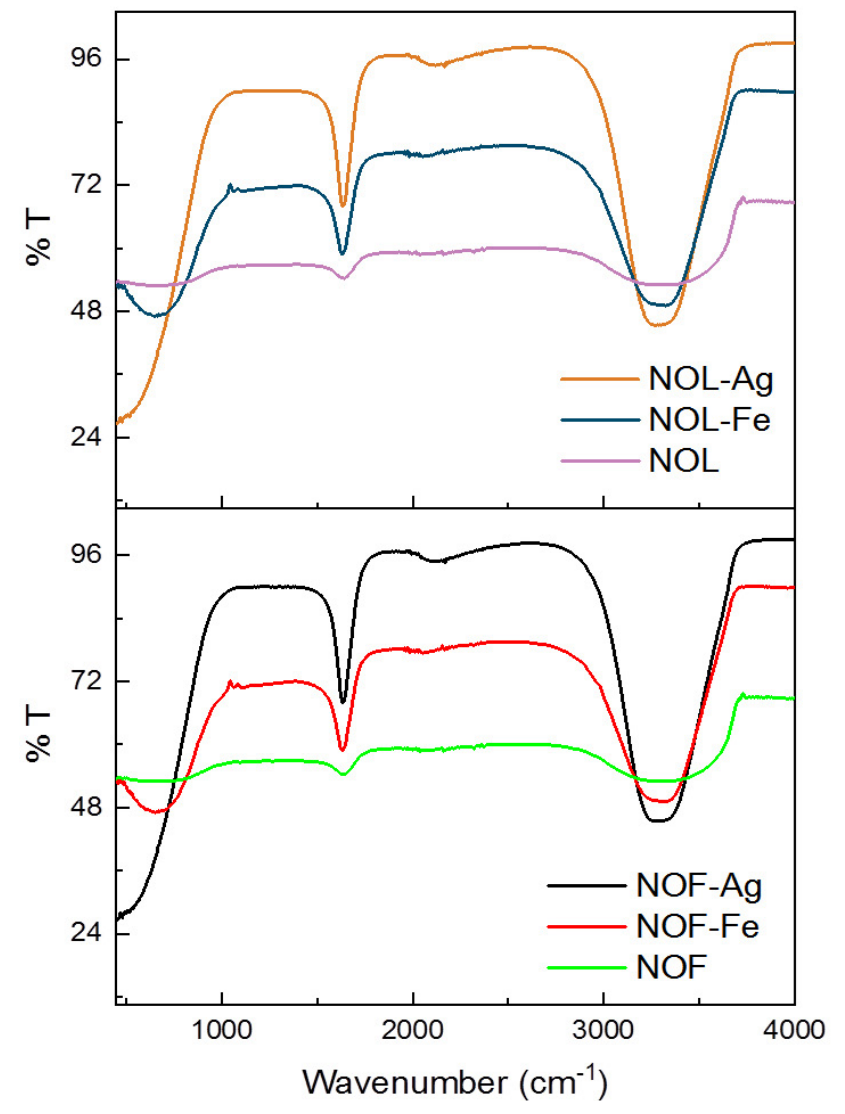

Figure 5. FTIR of NOL-Ag, NOL-Fe, NOF-Ag, NOF-Fe, and crude NOL and NOF extracts.

FeNPs $\left(\mathrm{IC}_{50}-7 \mathrm{uM}\right)$ are more variable than the NOL-FeNPs $\left(\mathrm{IC}_{50}-48 \mathrm{uM}\right)$. Our results suggested that NOL-Ag, NOF-Ag, NOF-Fe, and NOL-Fe are effective on the K562 cell line in low concentrations. Furthermore, we may conclude that NOF-Ag and NOF-Fe NPs have a cytotoxic effect on the K562 cell line in similar concentrations. However, NOL-Fe was cytotoxic at concentrations approximately 20 times higher than NOL-Ag (Fig. 6).

In other studies, $N$. oleander conjugated gold nanoparticles were synthesized to investigate in vitro anticancer activity on MCF-7 cell lines. $\mathrm{IC}_{50}$ values of these nanoparticles were found between 74.04 and $130.87 \mu \mathrm{g} / \mathrm{mL}$. These values are much higher than ours (Barai et al., 2018).

HUVECs were used in this study as a control. Ag and Fe NPs were not effective on HUVEC cells at the same concentrations. NOL-Ag $\left(\mathrm{IC}_{50}-100 \mathrm{uM}\right)$, NOF-Ag $\left(\mathrm{IC}_{50}-\right.$ $100 \mathrm{uM})$, NOF-Fe $\left(\mathrm{IC}_{50}-390 \mathrm{uM}\right)$, and NOL-Fe $\left(\mathrm{IC}_{50}-430 \mathrm{uM}\right)$. The concentrations of $\mathrm{Ag}$ and Fe NPs, which are cytotoxic on HUVEC cells, are more than ten-fold higher compared to K562 cells. These results show that nanoparticles are harmless to normal cells when used at low doses, which are cytotoxic to leukemia cells (Fig. 6).

\section{Antibacterial activity}

Based on the results in Table 4, the tested bacteria were able to be killed at a low concentration of $\mathrm{AgNO}_{3}(<0.00976 \mathrm{mM})$. The green-synthesized NOL-Ag and NOF-Ag were able to inhibit bacteria including multidrug pathogens. As showed in Table 5, the MIC $(\mathrm{mg} / \mathrm{mL} / \mathrm{mg} / \mathrm{mM})$ values of NOL-Ag and NOF-Ag against Gram-negative bacteria were ranged from $0.019 \mid 0.039$ to $0.3125 \mid 0.625$ and $0.078 \mid 0.156$, respectively. While the MIC $(\mathrm{mg} / \mathrm{mL} / \mathrm{mg} / \mathrm{mM})$ values of NOL-Ag and NOF-Ag against Gram-positive bacteria ranged from $0.078 \mid 0.156$ to $0.3125 \mid 0.625$ and $0.078 \mid 0.156$ to $0.625 \mid 1.25$, respectively. There is no significant difference observed between Gram-negative and Gram-positive bacteria including multi-resistant bacteria. The result of Fe-NPs was not given because the results were not effective.

Plant-derived essential oils and extracts have an antimicrobial effect with low toxicity and can be recommended as potential natural preservatives. According to Ríos \& Recio (2005), extracts can be classified as significant (MIC $<100 \mathrm{mg} / \mathrm{L}$ ), moderate $\quad(100<\mathrm{MIC} \leq 512 \mathrm{mg} / \mathrm{L}), \quad$ or weak (MIC $>512 \mathrm{mg} / \mathrm{L})$ depending on their respective activities against the corresponding pathogens. An important advantage for the used metallic ions is that silver ions have relatively low toxicity to human cells while adversely affecting bacteria and fungi by different mechanisms, including binding to the thiol groups of protein and denaturing them, programmed cell death (apoptosis), and causing the DNA to be in the condensed form (Lansdown, 2006; Mohamed et al., 2020).

Several studies documented the green synthesis of AgNPs using plant extracts. Also, antimicrobial effects of AgNPs against multidrug-resistant bacteria including E. coli, P. aeruginosa, and MRSA have been studied by many researchers (Rai et al., 2012; Paredes et al., 2014; Malik et al., 2015; Kar et al., 2016; Chauhan et al., 2017; Nagababu \& Rao, 2017). 

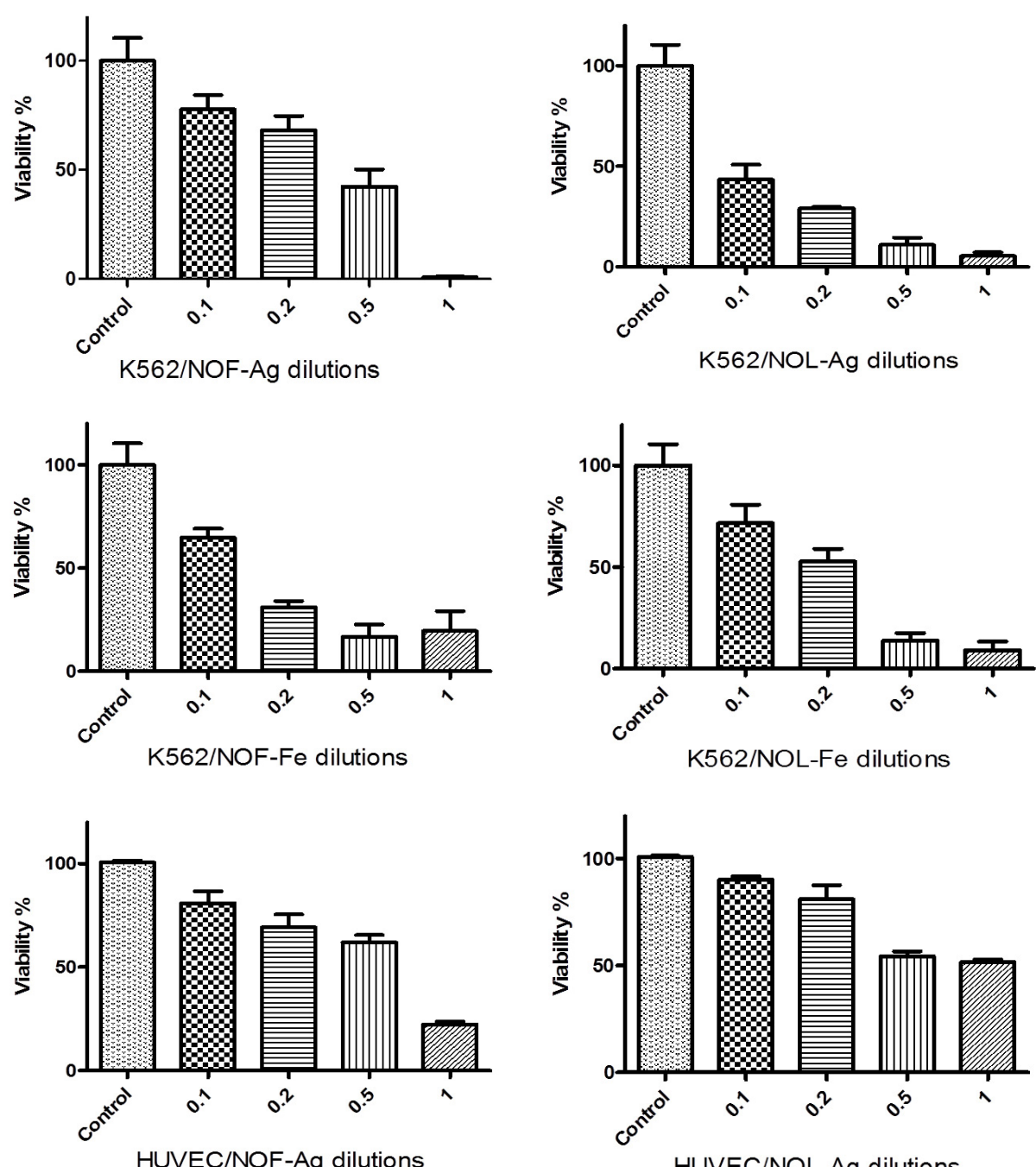

HUVEC/NOL-Ag dilutions
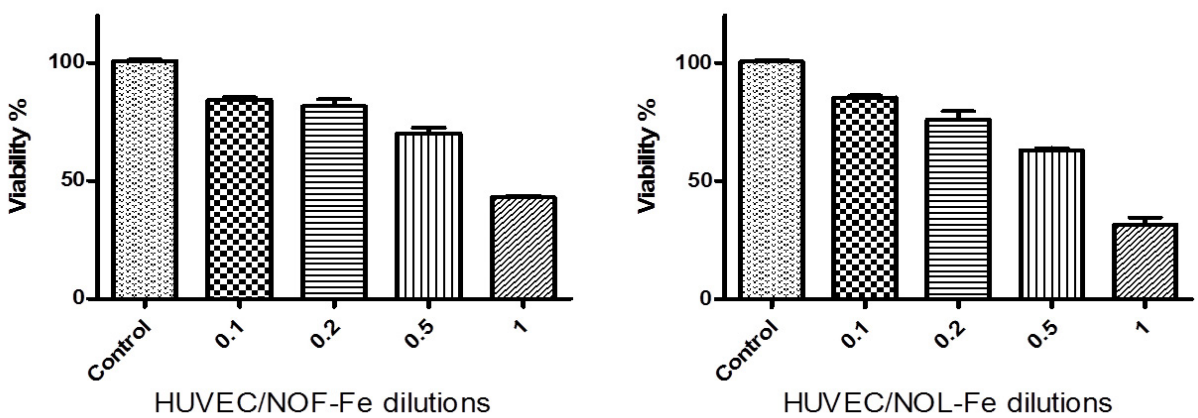

Figure 6. Cytotoxic activity of synthesized NOF-Ag, NOL-Ag, and NOF-Fe, NOL-Fe NPs against K562 and HUVEC cell lines.

\section{Conclusions}

Synthesized NPs have been successfully implemented in the fields of medicine and environmental remediation. The green synthesis of silver NPs was not only demonstrated by visual inspection and but also by performing systematic spectral techniques (UV-Vis absorption, FTIR spectroscopy, and SEM analysis). FTIR results proved that bioactive compounds responsible for silver bio-reduction could be proteins and flavonoids presumed to act as reducing and capping agents for the silver and iron nanoparticles. This research supports the idea that the total $\mathrm{pH}$ of the solution should be considered when making a medical evaluation. The SEM particle size for both NPs matches with DLS 
Table 5. The MICs of $\mathrm{AgNO}_{3}$, NOL-AgNPs, and NOF-AgNPs against Gram-negative and Gram-positive bacteria.

\begin{tabular}{lllll}
\hline No & Bacteria & $\begin{array}{l}\text { NOL-Ag NP } \\
(\mathrm{mg} / \mathrm{mL} \mid \mathrm{mg} / \mathrm{mM})\end{array}$ & $\begin{array}{l}\text { AgNO3 } \\
(\mathrm{mM})\end{array}$ & $\begin{array}{l}\text { NOF-AgNP } \\
(\mathrm{mg} / \mathrm{mL} / \mathrm{mg} / \mathrm{mM})\end{array}$ \\
\hline 1 & E. coli & $0.313 \mid 0.625$ & $<0.00976$ & $0.078 \mid 0.156$ \\
2 & CRKpn & $0.078 \mid 0.156$ & $<0.00976$ & $0.078 \mid 0.156$ \\
3 & CREc & $0.019 \mid 0.039$ & $<0.00976$ & $0.078 \mid 0.156$ \\
4 & S. aureus (ATCC 29213) & $0.156 \mid 0.313$ & $<0.00976$ & $0.625 \mid 1.250$ \\
5 & S. aureus (ATCC 25923) & $0.156 \mid 0.313$ & $<0.00976$ & $0.313 \mid 0.625$ \\
6 & ICRSa & $0.313 \mid 0.625$ & $<0.00976$ & $0.313 \mid 0.625$ \\
7 & hVISA & $0.313 \mid 0.625$ & $<0.00976$ & $0.313 \mid 0.625$ \\
8 & MRSA & $0.313 \mid 0.625$ & $<0.00976$ & $0.313 \mid 0.625$ \\
9 & MR-CoNS & $0.039 \mid 0.078$ & $<0.00976$ & $0.078 \mid 0.156$ \\
10 & MR-CoNS & $0.039 \mid 0.078$ & $<0.00976$ & $0.078 \mid 0.156$ \\
11 & VREf & $0.156 \mid 0.313$ & $<0.00976$ & $0.156 \mid 0.313$ \\
12 & E. faecalis (ATCC 51279) & $0.078 \mid 0.156$ & $<0.00976$ & $0.156 \mid 0.313$ \\
13 & VSEf & $0.039 \mid 0.078$ & $<0.00976$ & $0.078 \mid 0.156$ \\
14 & E. faecalis (ATCC 29212) & $0.3125 \mid 0.625$ & $<0.00976$ & $0.313 \mid 0.625$ \\
\hline
\end{tabular}

Note. CRKpn - clinical isolates of carbapenem-resistant Klebsiella pneumoniae; CREc - carbapenem-resistant Escherichia coli; ICRSa - inducible clindamycin-resistant Staphylococcus aureus BAA976-1; hVISA - heteroresistant S. aureus; MRSA - clinical isolates of methicillin-resistant S. aureus; MR-CoNS:2 - methicillinresistant coagulase-negative S. aureus; VREf - vancomycin-resistant Enterococcus faecium; VSEf - vancomycinsusceptible E. faecalis.

analysis, which was around $100 \mathrm{~nm}$. The green synthesized NO-AgNPs and NO-FeNPs are cytotoxic to the human chronic myeloid leukemia cells in low concentrations and not cytotoxic to the HUVEC cell line in the same concentrations. The tested bacteria were able to be killed at a low concentration of $\mathrm{AgNO}_{3}$ $(<0.00976 \mathrm{mM})$. The green synthesized NOLAgNPs and NOF-AgNPs were able to inhibit bacteria including multidrug pathogens. We can hypothesize here that green synthesis AgNPs can be decreased the cytotoxic effects of $\mathrm{AgNO}_{3}$ in vivo and the possible use of high doses of $\mathrm{AgNO}_{3}$ as antimicrobial drugs.

\section{Acknowledgements}

The authors would like to thank Professor Musa Mutlu Can from Istanbul University, Faculty of Science, Department of Physic, Renewable Energy and Oxide Hybrid Systems Laboratory for allowing us to use his laboratory and equipment.

\section{References}

Al-Badrani, B. A., Rhaymah, M. S., \& AlFarwachi, M. I. (2008). Acute toxicity of Nerium oleander. Iraqi Journal of Veterinary Sciences, 22(1), 1-4. https:/doi.org/10.33899/ijvs.2008.5665

Arya, V. (2010). Living systems: eco-friendly nanofactories. Digest Journal of Nanomaterials \& Biostructures, 5(1), 9-21.

Barai, A., Paul, K., Dey, A., Manna, S., Roy, S., Bag, B., \& Mukhopadhyay, C. (2018). Green synthesis of Nerium oleander-conjugated gold nanoparticles and study of its in vitro anticancer activity on MCF-7 cell lines and catalytic activity. Nano Convergence, 5, Article 10. https:/doi. org/10.1186/s40580-018-0142-5

Baytop, T. (1999). Curing with plants in Turkey, in the past and today. Iraqi Journal of Veterinary Sciences, 22, 1-4.

Bharathi, V., \& Shanthi, S. (2017). Green synthesis of silver nanoparticles from flower extract of Nerium oleander and its characterization. World Journal of Pharmaceutical Research, 6(6), 14101417. 
Bulut, G., \& Tuzlaci, E. (2013). An ethnobotanical study of medicinal plants in Turgutlu (ManisaTurkey). Journal of Ethnopharmacology, 149(3), 633647. https:/doi.org/10.1016/j.jep.2013.07.016

Byrne, F. P., Jin, S., Paggiola, G., Petchey, T. H. M., Clark, J. H., Farmer, T.J., Hunt, A.J., McElroy, C. R., \& Sherwood, J. (2016). Tools and techniques for solvent selection: green solvent selection guides. Sustainable Chemical Processes, 4, Article 7. https:// doi.org/10.1186/s40508-016-0051-z

Chaudhary, K. K., Prasad, D., Sandhu, B., \& Chaudhary, K. (2015). Preliminary pharmacognostic and phytochemical studies on Nerium oleander Linn. (white cultivar). Journal of Pharmacognosy and Phytochemistry, 4, 185-188.

Chauhan, S., Singh, M., Thakur, A., \& Dogra, M. S. (2017). Antibacterial activity of Nerium indicum against some Gram positive bacterial species. International Journal of Drug Research and Technology, 3(1), 8-11.

CLSI. (2018). M100 - Performance standards for antimicrobial susceptibility testing. 28th ed. Clinical and Laboratory Standards Institute.

Erdemoglu, N., Küpeli, E., \& Yeşilada, E. (2003). Anti-inflammatory and antinociceptive activity assessment of plants used as remedy in Turkish folk medicine. Journal of Ethnopharmacology, 89(1), 123-129. https://doi.org/10.1016/S0378$8741(03) 00282-4$

Erdogan, O., Abbak, M., Demirbolat, G.M., Birtekocak, F., Aksel, M., Pasa, S., \& Cevik, O. (2019). Green synthesis of silver nanoparticles via Cynara scolymus leaf extracts: the characterization, anticancer potential with photodynamic therapy in MCF7 cells. PLOS ONE, 14, Article e0216496. https://doi.org/10.1371/ journal.pone.0216496

Fedlheim, D. L., \& Foss, C. A. (2001). Metal nanoparticles: synthesis, characterization, and applications. CRC Press.

Gürdal, B., \& Kültür, Ş. (2013). An ethnobotanical study of medicinal plants in Marmaris (Muğla, Turkey).Journal of Ethnopharmacology, 146(1), 113126. https://doi.org/10.1016/j.jep.2012.12.012

Harborne, A. J. (1998). Phytochemical methods a guide to modern techniques of plant analysis. Springer science \& business media.

Kar, D., Bandyopadhyay, S., Dimri, U., Mondal, D. B., Nanda, P. K., Das, A. K., Batabyal, S., Dandapat, P., \& Bandyopadhyay, S. (2016). Antibacterial effect of silver nanoparticles and capsaicin against MDR-ESBL producing Escherichia coli: an in vitro study. Asian Pacific Journal of Tropical Disease, 6(10), 807-810. https:// doi.org/10.1016/S2222-1808(16)61135-0
Kiran, C., \& Prasad, D. N. (2014). A review on Nerium oleander Linn. (Kaner). International Journal of Pharmacognosy and Phytochemical Research, 6, 593-597.

Lansdown, A. B. (2006). Silver in health care: antimicrobial effects and safety in use. In: U.-C. Hipler \& P. Elsner (Eds), Biofunctional textiles and the skin (pp. 17-34). Karger Publishers. https:// doi.org/10.1159/000093928

Malik, R., Bokhari, T. Z., Siddiqui, M. F., Younis, U., Hussain, M. I., \& Khan, I. A. (2015). Antimicrobial activity of Nerium oleander L. and Nicotiana tabacum L.: a comparative study. Pakistan Journal of Botany, 47(4), 1587-1592.

Mohamed, D. S., El-Baky, R. M. A., Sandle, T., Mandour, S. A., \& Ahmed, I. F. (2020). Antimicrobial activity of silver-treated bacteria against other multi-drug resistant pathogens in their environment. Antibiotics, 9(4), Article 181. https://doi.org/10.3390/ antibiotics 9040181

Mosmann, T. (1983). Rapid colorimetric assay for cellular growth and survival: application to proliferation and cytotoxicity assays. Journal of Immunological Methods, 65(1-2), 55-63. https:// doi.org/10.1016/0022-1759(83)90303-4

Nagababu, P., \& Rao, V. U. (2017). Pharmacological assessment, green synthesis and characterization of silver nanoparticles of Sonneratia apetala Buch.Ham. Ieaves. Journal of Applied Pharmaceutical Science, 7(8), 175-182. https://doi.org/10.7324/ japs.2017.70824

Paredes, D., Ortiz, C., \& Torres, R. (2014). Synthesis, characterization, and evaluation of antibacterial effect of $\mathrm{Ag}$ nanoparticles against Escherichia coli 0157:H7 and methicillin-resistant Staphylococcus aureus (MRSA). International Journal of Nanomedicine, 9(1), 1717-1729. https://doi.org/10.2147/IJN. S57156

Pathak, S., Multani, A. S., Narayan, S., Kumar, V., \& Newman, R. A. (2000). Anvirzel ${ }^{\mathrm{TM}}$, an extract of Nerium oleander, induces cell death in human but not murine cancer cells. Anti-Cancer Drugs, 11, 455-463. https://doi.org/10.1097/00001813200007000-00006

Rai, M. K., Deshmukh, S. D., Ingle, A. P., \& Gade, A. K. (2012). Silver nanoparticles: the powerful nanoweapon against multidrugresistant bacteria. Journal of Applied Microbiology, 112(5), 841-852. https://doi.org/10.1111/j.13652672.2012.05253.x

Ríos, J. L., \& Recio, M. C. (2005). Medicinal plants and antimicrobial activity. Journal of Ethnopharmacology, 100(1-2), 80-84. https://doi. org/10.1016/j.jep.2005.04.025 
Rubini, S., Rossi, S. S., Mestria, S., Odoardi, S., Chendi, S., Poli, A., Merialdi, G., Andreoli, G., Frisoni, P., Gaudio, R. M., Baldisserotto, A., Buso, P., Manfredini, S., Govoni, G., Barbieri, S., Centelleghe, C., Corazzola, G., Mazzariol, S., \& Locatelli, C. A. (2019). A probable fatal case of oleander (Nerium oleander) poisoning on a cattle farm: a new method of detection and quantification of the oleandrin toxin in rumen. Toxins, 11(8), Article 442. https://doi.org/10.3390/ toxins11080442

Sağıroğlu, M., Dalgıccedil, S., \& Toksoy, S. (2013). Medicinal plantsused in Dalaman(Muğla), Turkey. Journal of Medicinal Plants Research, 7, 2053-2066. https://doi.org/10.5897/JMPR2013.2590

Santhi, R. (2011). Phytochemical screening of Nerium oleander leaves and Momordica charantia leaves. International Research Journal of Pharmacy, 2, 131-135.

Saranya, S., Archana, D., \& Santhy, K. (2017). Antimicrobial and antioxidant effects of Nerium oleander flower extracts. International Journal of Current Microbiology and Applied Sciences, 6(5), 1630-1637. https://doi.org/10.20546/ ijcmas.2017.605.178

Sikarwar, M. S., Patil, M. B., Kokate, C. K., Sharma, S., \& Bhat, V. (2009). Antidiabetic activity of Nerium indicum leaf extract in alloxan-induced diabetic rats. Journal of Young Pharmacists, 1(4), 340-345.
Singhal, K.G., \&Gupta, G.D.(2012). Hepatoprotective and antioxidant activity of methanolic extract of flowers of Nerium oleander against CCl4-induced liver injury in rats. Asian Pacific Journal of Tropical Medicine, 5(9), 677-685. https://doi.org/10.1016/ S1995-7645(12)60106-0

Turan, N., Akgün-Dar, K., Kuruca, S. E., KiliçaslanAyna, T., Seyhan, V. G., Atasever, B., Meriçli, F., \& Carin, M. (2006). Cytotoxic effects of leaf, stem and root extracts of Nerium oleander on leukemia cell lines and role of the p-glycoprotein in this effect. Journal of Experimental Therapeutics \& Oncology, 6(1), 31-38.

Tyler, V. E. (1993). Phytomedicines in Western Europe: potential impact on herbal medicine in the United States. ACS Publications.

Wang, Z., Liu, Y., Huang, B., Dai, Y., Lou, Z., Wang, G., Zhang, X., \& Qin, X. (2014). Progress on extending the light absorption spectra of photocatalysts. Physical Chemistry Chemical Physics, 16(7), 27582774. https://doi.org/10.1039/C3CP53817F

Wong, S. K., Lim, Y. Y., Abdullah, N. R., \& Nordin, F.J. (2011). Antiproliferative and phytochemical analyses of leaf extracts of ten Apocynaceae species. Pharmacognosy Research, 3(2), 100-106. https://doi.org/10.4103/0974-8490.81957

Zibbu, G., \& Batra, A. (2010). A review on chemistry and pharmacological activity of Nerium oleander L. Journal of Chemical and Pharmaceutical Research, 2, 351-358.

\section{Зелений синтез та характеристика наночастинок срібла та заліза отриманих з використанням екстрактів Nerium oleander та їх антибактеріальна та протипухлинна активність}

Шаліма Шавуті 1, Часан Байрам 2, Ахмет Беятли ${ }^{3}$, Ішак Афшін Каріпер ${ }^{4}$, Исик Неслішах Коркут ${ }^{\text {, }}$ Зеррін Акташ ${ }^{5}$, Мустафа Орал Онцюл ${ }^{6}$, Серап Ердем Куруца ${ }^{1}$

\footnotetext{
${ }^{1}$ Кафедра фізіології, медичний факультет Стамбульського університету, вул. Тургута Озала Міллета, Стамбул, 34093, Туреччина

2 Лабораторія відновлюваних джерел енергії та оксидних гібридних систем, кафедра фізики, факультет природничих наук Стамбульського університету, вул. Шехзадебаші, Стамбул, 34134, Туреччина

3 Кафедра лікарських та ароматичних рослин Гамідійського професійно-технічного училища охорони здоров'я Університету медико-санітарних наук, вул. Тібій $\epsilon, 38$, Стамбул, 34668, Туреччина

${ }^{4}$ Педагогічний факультет університету Ерджієс, Єнідоган Махаллесі, вул. Турхан Байтоп Сокак, 1, Кайсері, 38280, Туреччина

${ }^{5}$ Кафедра мікробіології, медичний факультет Стамбульського університету, вул. Тургута Озала Міллета, Стамбул, 34093, Туреччина

${ }^{6}$ Кафедра інфекційних захворювань, медичний факультет Стамбульського університету, вул. Тургута Озала Міллета, Стамбул, 34093, Туреччина
} 
Лікарські рослини можуть використовуватися як відновники при одержанні наночастинок металів шляхом зеленого синтезу. Отримані наночастинки характеризуються хіміотерапевтичним та протиінфекційним властивостям природних сполук. Зокрема, у цій праці йдеться про зелений синтез наночастинок срібла та заліза з використанням екстрактів листя та квіток Nerium oleander, a також аналізується їх властивості як протипухлинних та протимікробних засобів. Повідомляється про особливості виготовлення наночастинок загалом та структурну характеристику наночастинок срібла та заліза зокрема. Формування наночастинок досліджено за допомогою сканувальної електронної мікроскопії та енергодисперсійної рентгенівської спектроскопії, UV-Vis та інфрачервоної спектроскопії з перетворенням Фур'є (FTIR). Окрім того, також було досліджено поверхневим заряд, розміри і розподілом наночастинок за допомогою DLS аналізу. Зелений синтез наночастинок срібла та заліза з використанням N. oleander показав різні рівні селективної цитотоксичності щодо К562 (клітини хронічної мієлоїдної лейкемії людини) у низьких концентраціях і не був цитотоксичним для HUVEC (ендотеліальні клітини пупкової вени людини) у тих же концентраціях. Наночастинки срібла виявляли антибактеріальну активність по відношенню до мультирезистентних патогенів, тоді як наночастинки заліза не виявляли такої активності. Результати цього дослідження підтверджують потенціал використання наночастинок зеленого синтезу у різних сферах біомедицини та фармацевтики в майбутньому.

Ключові слова: Nerium oleander, зелений синтез, Ag-наночастинки, Fе-наночастинки, клітинна цитотоксичність, антибактеріальний ефект 